\title{
AUTOMATIZÁLT PNEUMATIKUS SZELEP VESZTESÉGMÉRŐ MEGALKOTÁSA
}

\section{AUTOMATIZED SYSTEM FOR MEASURING FLOW LOSSES OF PNEUMATIC VALVES}

\author{
Sipos Kristóf Balázs ${ }^{1}$, Tóth János ${ }^{2}$ \\ Debreceni Egyetem, Müszaki kar, Villamosmérnöki és Mechatronikai Tanszék, 4028, \\ Magyarország, Debrecen, Ótemetö utca, 2-4 \\ 'siposk94@gmail.com²tothjanos@eng.unideb.hu
}

\begin{abstract}
The pneumatic devices are frequently used in several fields of the industry but the losses and pressure drops of the pneumatic system are not really investigated. These losses can cause great property damages during long uptime because the compressed air is a quite expensive energy source. I designed a measuring system which is able to measure the friction losses of electro-pneumatic 5/2-way valves (monostable and bistable too). It is possible to choose between manual and automatic operation modes as well. In the automatic mode the system makes measurements in three different user-defined pressure levels. In the manual mode the measuring pressure can be set between 2-6 bars. An automatic evaluate program is also an important part of the created system. It gives the possibility of the fast evaluation of the saved data and it could be the base of a fast report generating application.
\end{abstract}

Keywords: pneumatic valve, flow loss, PLC, HMI, data aquisition

\section{Összefoglalás}

Az iparban számos területen alkalmaznak pneumatikus berendezéseket, azonban a pneumatikus rendszerekben fellépő veszteségekkel, nyomásesésekkel keveset foglalkoznak. Mivel a sürített levegő igen drága energiaforrás, ezért ezek a veszteségek hosszú üzemidő alatt igen nagy anyagi károkat okozhatnak. Az általunk megtervezett mérörendszer alkalmas 5/2-es elektropneumatikus szelepek (monostabil és bistabil is) áramlási veszteségének a mérésére. A felhasználónak lehetősége van automatikus és manuális üzemmódok közül választani. Automatikus üzemmódban a rendszer három nyomásértéken végez méréseket, melyet a kezelő határoz meg. Manuális üzemmódban a mérési nyomás szabadon állítható 2-6 bar-os tartomány között. A rendszerhez tartozik egy automatikus kiértékelő program is. Ezzel az alkalmazással gyors adatfeldolgozás valósítható meg, mellyel a gyors jegyzőkönyv készítés alapjait lehet megteremteni.

Kulcsszavak: pneumatikus szelep, áramlási veszteség, PLC, HMI, mérésadatgyüjtés

\section{Bevezetés, előzmények}

A szakirodalomban több módszer is létezik a különböző szelepjellemzők mérésé- re illetve számolására. Magyarországon jelenleg nem található hatályos, érvényben lévő szabvány, ami pontosan meghatározná, hogy a szelepek átömlési karakteriszti- 
káját hogyan kell meghatározni. Azonban 2015.05.01-ig érvényben volt ezzel a témával foglalkozó MSZ ISO 6358 szabvány, amely $20 \mathrm{~mm}$-nél kisebb átömlési furattal rendelkező szelepek mérését határozza meg. Az említett szabvány előírja, hogy mérés közben legalább egy keresztmetszeten az áramlás sebességének el kell érnie a hangsebességet, az ilyen áramlást fojtásos áramlásnak nevezi. A szabvány a számolás menetét is pontosan meghatározza hangsebesség feletti áramlás esetén, illetve kitér arra is, hogyan kell számolni hangsebesség alatti áramlás esetén.

A japán JFPS 2009:2002 szabvány már alkalmas $20 \mathrm{~mm}$-nél nagyobb átömlési furattal rendelkező szelepek mérésére, azonban ez is hangsebesség feletti áramlást ír elö. A szakirodalmi áttekintés során nem találtunk olyan rendszert, amely hangsebesség alatti áramlás esetén is alkalmazható és automatikus kiértékelést tesz lehetővé. [1],[2][3],[4]

\section{Az elektropneumatikus kapcso- lás felépítése}

A rendszer elkészítésének első lépése a pneumatikus kapcsolás megtervezése volt. A pneumatikus kapcsolás megvalósításához a Festo által fejlesztett FluidSIM v4.2 programot használtuk fel. Az elkészített kapcsolás az 1. ábrán látható. A kapcsoláshoz felhasznált elemek a következőek: 1. kompresszor, 2. levegő előkészítő, 3. proporcionális szelep, 4. 5/2-es előtöltö szelep, 5. áramlásmérő szenzor, 6. és 10. nyomásmérő szenzorok, 7. logikai „,vagy” szelep 8. mérni kívánt szelep, 9. visszacsapó szelepek, 11. puffer tartály, 12. 3/2es leeresztő szelep, 13. fojtószelep.

A kapcsolás müködése a következö: alapesetben, a puffer tartályban csak az atmoszférikus nyomás tapasztalható. Amint a kezelő a HMI-n keresztül beállítja a mérési tartományt, az 1. ábrán jelölt „előtöltő szelep” a 9-es jelü visszacsapó szelepen keresztül elkezdi a puffer tartályt tölteni, ilyenkor az 3/2-es ,leeresztő szelep" (1. ábra 12. elem) zárva van egészen addig, amíg a beállított nyomás meg nem közelíti a tartály nyomását 0,5 bar különbséggel.

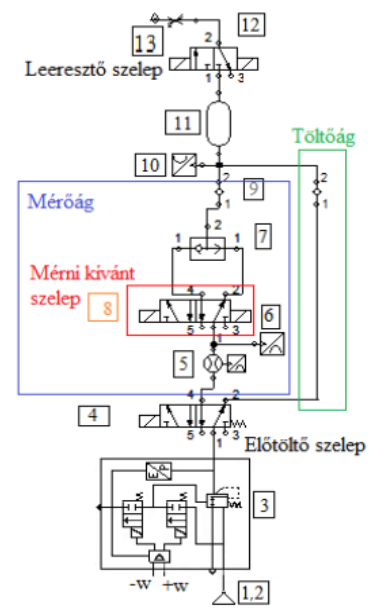

1. ábra. A megvalósitott elektropneumatikus kapcsolás

Erre azért van szükség, mert a rendszer így hozza létre a szükséges ellenoldali nyomást a szelep méréséhez, ezáltal a mérés már nem terheletlen állapotból indul. Ha kialakult a kívánt nyomás a tartályban, a töltő szelep átkapcsol és a 3-as jelü proporcionális szelep már a kívánt mérési nyomást állítja elő. A „elötöltő szelep” átkapcsolásával egy időben nyit a 13-assal jelölt „leeresztő szelep” is, így a „mérőágon" létrejön a kívánt áramlás. Annak érdekében, hogy az áramlás értéke ne haladja meg az áramlásmérő (1. ábra 5. elem) mérési tartományát (5-50 1/perc), beépítésre került egy állítható fojtó szelep (1. ábra 13. elem), melyet úgy állítottunk be, hogy alapesetben 20-25 1/perc legyen a mérőmüszeren az áramlás, így még a hirtelen kiugró változás értékekeit is mérni tudja az áramlásmérő szenzor. Ez az állapot egészen addig tart, amíg le nem telik a kezelő által beállított mérésidő. Ha letelt, a „töltőszelep” ismételten tölteni kezdi a 
puffer tartályt, hogy a következő nyomásértéknél is terhelt állapotban legyen a rendszer. Ez a töltési folyamat ugyanúgy zajlik, ahogy azt korábban leírtuk. Amint a rendszer végigmérte a három nyomásértéket, a program átváltja az 5/2-es 8 . jelü mérendő szelepet az 1-2 irányról az 1-4 irányra. Eközben a puffer tartály nyomását folyamatosan engedi le a ,leeresztő szelep", hogy 1-4 irányban is azonos elötöltéssel tudja végrehajtani a mérési folyamatot. Ha megtörtént a mérés 1-2 és 1-4 irányokban is, a rendszer visszatér alapállapotba, egészen a következő mérés indításáig.

\section{Mérési eredmények feldolgozása}

A mérés gyors kiértékelése érdekében létrehoztunk egy Visual Basic for Applications-ben elkészített programot, amelyben néhány kattintással a szelep(ek) mérése során kapott értékek kiértékelhetök. A programba beépítésre került egy jegyzőkönyv mentése funkció is, ezzel a funkcióval könnyen készíthető mérési jegyzőkönyv a szelepröl. Ez a program automatikusan számolja ki az átlag nyomáseséseket és áramlási értékeket a mérési tartományokon úgy, hogy a puffer tartály töltéséből adódó tranziens értékeket elhanyagolja. A kezelő felületen az adatok beolvasására kattintva kezdhet a felhasználó új mérés kiértékelésébe. A bemeneti adatok kitöltése jegyzőkönyv készítéséhez fontos. Adat beolvasás után a rendszer megkezdi a kiértékelést, amint a mérés kiértékelése gombra kattint a kezelő. A program az előző két mérési ponthoz képest vizsgálja, hogy hány százalékban tér el az aktuális mérési pont az előzőekhez képest, így csak a közel lineáris szakaszokat veszi figyelembe, ahol a terhelés közel állandó. Erre azért van szükség, hogy azonos körülmények között történt mérési eredményeket hasonlítson össze, az átmeneti szakaszokat, amelyek a puffer tartály töltéséből adódnak, elhanyagolja. Ezeken a szakaszokon számol egy átlagos nyomásesést és áramlási értéket 1-2 és 1-4 irányokra is, melyeket a 2 . ábra mutat.

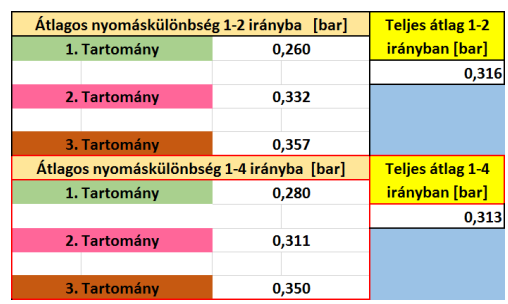

2. ábra. Kezelöfelület 2. részlet

A program egy összegző táblázatot is kitölt, amiben a szelep két állapota közötti eltérés látható áramlási és nyomás értékekre (3. ábra, 4. ábra).

\begin{tabular}{|c|c|c|c|}
\hline \multicolumn{2}{|c|}{ Nyomáskülönbségek eltérése } & \multirow{2}{*}{$\begin{array}{c}\text { Eltérés 1-2 } \\
\text { irányhoz képest } \\
{[\%]}\end{array}$} & \multirow{2}{*}{\begin{tabular}{|c|} 
Eltérés 1-4 \\
irányhoz képest \\
\end{tabular}} \\
\hline Tartomány & Eltérés [bar] & & \\
\hline 1. & 0,020 & 6,31 & 6,37 \\
\hline 2. & 0,021 & 6,61 & 6,68 \\
\hline 3. & 0,008 & 2,45 & 2,47 \\
\hline
\end{tabular}

3. ábra. Nyomásértékek eltérése - részlet

\begin{tabular}{|c|c|c|c|}
\hline \multicolumn{2}{|c|}{ Áramlási sebességek eltérése } & \multirow{2}{*}{$\begin{array}{c}\text { Eltérés 1-2 } \\
\text { irányhoz képest } \\
{[\%]}\end{array}$} & \multirow{2}{*}{\begin{tabular}{|c|} 
Eltérés 1-4 \\
irányhoz képes \\
\end{tabular}} \\
\hline Tartomány & Eltérés [1/perc] & & \\
\hline 1. & 0,978 & 5,55 & 5,64 \\
\hline 2. & 1,236 & 7,00 & 7,12 \\
\hline 3. & 2,607 & 3,67 & 3,73 \\
\hline
\end{tabular}

4. ábra. Áramlási sebességek eltérése - részlet

Az összes számolt és beolvasott adatból a program hét különböző grafikont készít el. Az elsőn egy teljes mérési adatsor látható (5. ábra -szürke és sárga nyomás értékek, kék pedig az áramlási értékeket jelöli).

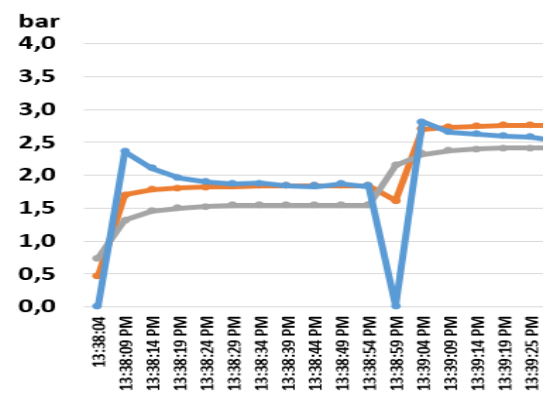

5. ábra. Teljes mérési adatsor - részlet 
A könnyebb megértés érdekében a program a teljes mérési adatsoron látott grafikonokat szétválogatja és külön külön is megjeleníti, valamint elkészíti a teljes adatsorhoz tartozó nyomáskülönbség grafikont is. Látható, hogy a puffer tartály töltésénél ezen a grafikonon nullás értékek is megjelenhetnek (5. ábra, kék grafikon), ezeknek a figyelembe vétele hibás következtetéseket eredményezne, ezért szükséges ezen szakaszok elhanyagolása. A töltési szakaszok elhanyagolása után az algoritmus elkészíti az áramlási értékekre (6. ábra) és nyomáskülönbségekre (7. ábra) vonatkozó grafikonokat.

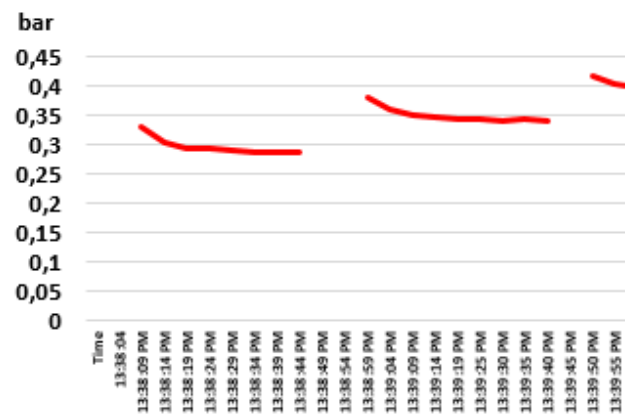

6. ábra. Áramlási értékek - részlet

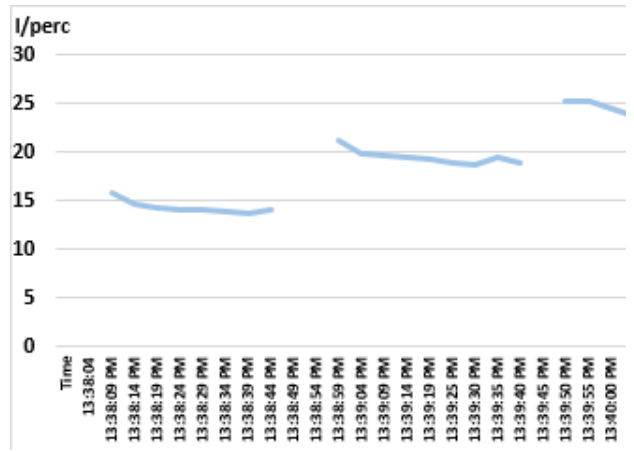

7. ábra. Nyomáskülömbségek - részlet

A jegyzőkönyv mentése gombra kattintva a program automatikusan elmenti a kiértékelt mérési eredményeket egy PDF dokumentumba.

\section{Következtetések}

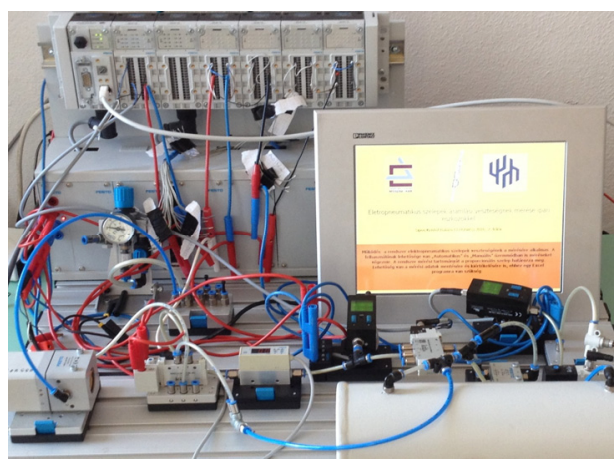

8. ábra. Általunk megvalósitott mérörendszer

A rendszer (8. ábra) egy gyors és egyszerü mérési és kiértékelési folyamatot valósít meg, ami ipari körülmények között is lehetővé teszi, hogy a szelepeket nagyobb hatékonysággal müködtethessük. Ezzel végeredményben pedig egy hatékonyabban, megbízhatóbban müködtethető és energiatakarékosabb gyártástechnológiát valósíthatunk meg, ahol a veszteségeket csökkenthetjük, és ez hosszútávon olcsóbb termékek előállításához vezethet.

\section{Szakirodalmi hivatkozások}

[1.] MSZ ISO 6358:1995 Pneumatikus energiaátvitel. Összenyomható munkaközeggel müködö elemek. Áramlási jellemzők meghatározása.

[2.] JFPS 2009:2002, Test method for flow-rate characteristics of pneumatic components using charge method.

[3.] JIS B 8390:2000, Pneumatic Fluid Power Components Using Compressible Fluids Determination of Flow-rate Characteristics.

[4.] S. de las Heras: $A$ new experimental algorithm for the evaluation of the true sonic conductance of pneumatic components using the characteristic unloading time. In: International Journal of Fluid Power, Volume 2, 2001. 